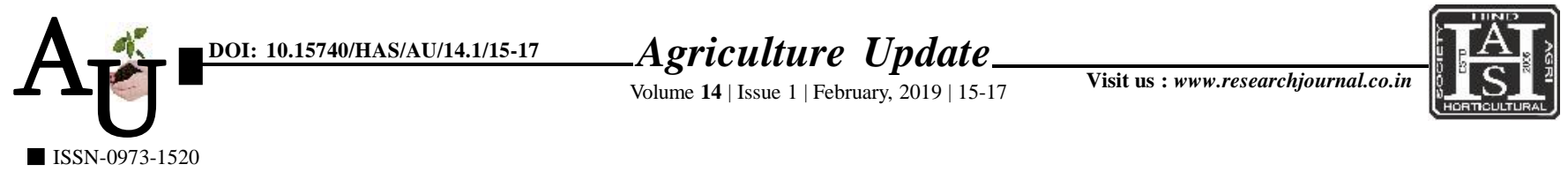

\title{
Research Article: A study on knowledge level of crisis management practices of castor growers
}

\section{B. H. Tavethiya, V. J. Savaliya and A. M. Fulmaliya}

Article Chronicle : Received : 25.05.2018;

Revised : 27.12.2018; Accepted :

03.01.2019

KEY WoRds:

Knowledge, Crisis management, Castor cultivation

\section{Author for correspondence:}

\section{B.H. Tavethiya} Directorate of Extension Education, Junagadh Agricultural University, Junagadh (Gujarat) India Email:tavethiya@jau.in

See end of the article for authors' affiliations
SUMMARY : Castor (Ricinus communis L.) is one of the most ancient, non-edible, medicinal and industrial oilseed crops of the country. Castor is indigenous to Eastern Africa and most probably originated in Ethiopia. India contributes more than one third of the world production of castor oil and meets about 80 per cent world castor oil demands. The knowledge about crisis management in castor is important aspect to improve the production of castor.A multistage random sampling technique was used for the selection and study of 180 respondents. Majority (78.33\%) of the respondents had medium knowledge level of crisis management practices; whereas 15.00 and 6.67 per cent of respondents had low and high level of knowledge about crisis management practices, respectively.

How to cite this article : Tavethiya, B.H., Savaliya, V.J. and Fulmaliya, A.M. (2019). A study on knowledge level of crisis management practices of castor growers. Agric. Update, 14(1): 15-17; DOI : 10.15740/HAS/AU/ 14.1/15-17. Copyright@ 2019: Hind Agri-Horticultural Society. 